\title{
Letting the managers manage: analyzing capacity to conserve biodiversity in a cross-border protected area network
}

\author{
Sarah Clement $^{1}, \underline{\text { Susan A. Moore }}^{2}$ and Michael Lockwood ${ }^{3}$
}

\begin{abstract}
Biodiversity loss is one of the most significant drivers of ecosystem change and is projected to continue at a rapid rate. While protected areas, such as national parks, are seen as important refuges for biodiversity, their effectiveness in stemming biodiversity decline has been questioned. Public agencies have a critical role in the governance of many such areas, but there are tensions between the need for these agencies to be more "adaptive" and their current operating environment. Our aim is to analyze how institutions enable or constrain capacity to conserve biodiversity in a globally significant cross-border network of protected areas, the Australian Alps. Using a novel conceptual framework for diagnosing biodiversity institutions, our research examined institutional adaptive capacity and more general capacity for conserving biodiversity. Several intertwined issues limit public agencies' capacity to fulfill their conservation responsibilities. Narrowly defined accountability measures constrain adaptive capacity and divert attention away from addressing key biodiversity outcomes. Implications for learning were also evident, with protected area agencies demonstrating successful learning for on-ground issues but less success in applying this learning to deeper policy change. Poor capacity to buffer political and community influences in managing significant cross-border drivers of biodiversity decline signals poor fit with the institutional context and has implications for functional fit. While cooperative federalism provides potential benefits for buffering through diversity, it also means protected area agencies have restricted authority to address cross-border threats. Restrictions on staff authority and discretion, as public servants, have further implications for deploying capacity. This analysis, particularly the possibility of fostering "ambidexterity" - creatively responding to political pressures in a way that also achieves a desirable outcome for biodiversity conservation-is one promising way of building capacity to buffer both political influences and ecological pressures. The findings and the supporting analysis provide insight into how institutional capacity to conserve biodiversity can be enhanced in protected areas in Australia and elsewhere, especially those governed by public agencies and/or multiple organizations and across jurisdictions.
\end{abstract}

Key Words: adaptive governance; Australian Alps; biodiversity conservation; capacity; institutions; protected area management

\section{INTRODUCTION}

Globally, biodiversity loss ranks as one of the most significant drivers of ecosystem change (Hooper et al. 2012), but the pace of decline shows no signs of slowing as pressures on ecosystems increase (Butchart et al. 2010). Land use change, invasive species, and climate change are among the most significant drivers of biodiversity loss (Sala et al. 2000). Addressing these threats requires better coordination of conservation across landscapes (Likens and Lindenmayer 2012, Wyborn 2015). In this context, large, well-designed and managed protected areas can play an important role in meeting conservation targets and can help slow the rate of biodiversity loss (Butchart et al. 2012). Protected areas are places that are recognized, dedicated, and managed to achieve long-term conservation (Dudley 2008), but the effectiveness of these areas in conserving biodiversity has been widely debated. While many factors have been blamed for the continued loss of biodiversity despite expansion of protected areas, part of the critique centers on how poor governance has undermined social and ecological outcomes (Mora and Sale 2011, Le Saout et al. 2013, Dudley et al. 2014, Hill et al. 2015).

Institutions are the rules and norms that structure, stabilize, and provide meaning to social life (Scott 2014). They provide constraints and opportunities, thereby influencing the behavior of individuals and organizations and determining subsequent consequences of that behavior (McGinnis 2011). Institutions also support the capacity of actors to adapt to environmental change and are capable of influencing the trajectory of social-ecological systems (SESs) (Chaffin et al. 2014). Understanding institutions and governance can thus help identify critical points of intervention and support improved decision-making and better biodiversity outcomes in protected areas.

Our aim is to analyze how institutional conditions enable or constrain the capacity to conserve biodiversity in a cross-border protected area network in the Australian Alps (the Alps). The focus is on public agencies because although governance of protected areas increasingly involves nonstate actors, government agencies still play a major role in governing these areas on their own and as partners. In many areas, including the Australian Alps, public agencies have high levels of responsibility for solving public problems, which makes them a critical part of the solution (Ansell 2011). The Australian Alps provides an ideal case study location to examine government-managed protected areas, as well as landscape-scale cooperation, because the network of internationally significant protected areas covers three subnational jurisdictions.

In complex SESs and under conditions of rapid environmental change, many researchers have highlighted the need for adaptive capacity. Adaptive capacity of institutions is defined as the "characteristics of institutions that empower social actors to respond to short and long-term impacts either through planned measures or through allowing and encouraging creative responses

${ }^{1}$ Department of Geography and Planning, School of Environmental Sciences, University of Liverpool, ${ }^{2}$ Environment and Conservation Sciences, School of Veterinary and Life Sciences, Murdoch University, ${ }^{3}$ Geography and Spatial Sciences, School of Land and Food, University of Tasmania 
from society" (Gupta et al. 2010:461). These institutional characteristics are essential for effective conservation, but adaptive capacity is insufficient if foundational knowledge and skills (i.e., general capacity) are missing. General capacity is the ability to identify and solve problems and deploy knowledge and skills (Virji et al. 2012). We focus on both types of capacity.

The inherent uncertainty, complexity, and nonlinear dynamics of SESs are challenging for traditional, centralized, efficiency-driven approaches (Chaffin et al. 2014) that can characterize protected area management agencies. Adaptive governance has been proposed as an alternative to current arrangements, under the premise that it emphasizes a more experimental, learning-driven approach (Brunner 2010, Chaffin et al. 2014). Ideally, adaptive governance consists of multilayered governance networks fostering learning, building social capital, and linking across vertical and horizontal scales; polycentricity; and deliberative decision-making (Dietz et al. 2003, Folke et al. 2005, Armitage et al. 2012). Implementation of adaptive governance in practice remains slow, however, and advancing it requires an understanding of institutions and the social, political, and other factors that influence institutional adaptive capacity (Koontz et al. 2015).

There is a critical need to examine the practicality of calls to be more "adaptive" given the administrative limits of key actors, especially government agencies (Eakin et al. 2011, Rijke et al. 2012, Wyborn and Dovers 2014). This operating environment includes tight budgets and timescales, limiting political and statutory mandates, inflexible accountability measures, and rigid administrative control due to low levels of public trust (Ansell 2011, Wyborn and Dovers 2014). What is poorly understoodand examined in this study - is how the operating environments of public agencies reinforce or undermine adaptive capacity. The examination draws on both adaptive and general capacity to provide insights. A particular interest is how the operating environments of public agencies can enable or constrain capacity, thereby creating poor institutional fit.

\section{METHODS}

We adopted an institutional diagnostic method. The focus here is on diagnosing the aspects of biodiversity conservation that are salient for problem-solving by asking a series of questions to determine the sources of institutional problems in order to recommend appropriate solutions, guided by the methodology developed by Young (2008). A diagnosis investigates whether institutions have the capacity to deal with environmental problems using the concept of institutional fit. Based on the principle that institutional dimensions should be tailored to the requirements of environmental problems (Young 2008), fit considers whether institutions match the spatial, temporal, and functional aspects of the ecosystems governed (Boyd and Folke 2011). Poor functional fit, for example, is where institutions fail to respond adequately to drivers that could have been buffered, fail to buffer between socioeconomic and biophysical systems, or deploy responses that are mistimed, misdirected, or nonexistent (Galaz et al. 2008). The concept of fit is used more broadly here than in the adaptive governance literature, considering political fit; i.e., whether institutions are adapted to their socio-political environment (Goodin 1996).

\section{Conceptual framework}

A novel conceptual framework (Clement et al. 2016) guided diagnosis. The framework has four categories of focus: problems and players, politics, competence, and capacity (Fig. 1, segments of the circle). These categories subdivide into elements (Fig. 1, boxed words). The framework was designed specifically to analyze biodiversity institutions. Although the concepts of general and adaptive capacity align closely with the competence and capacity categories, elements in the other two categories can exert a strong influence on capacity (Fig. 1, arrows), as the diagnosis we use illustrates. The framework draws on adaptive governance, including the concepts of buffering and self-organizing, as well as the institutional literature, especially organizational studies and public administration. This broad approach ensures the diagnostic attends to more general capacity issues (e.g., administrative competence) and the wider institutional context (e.g., framing, interplay) in which organizations responsible for conserving biodiversity operate.

Fig. 1. Diagram of conceptual framework used in this diagnosis.

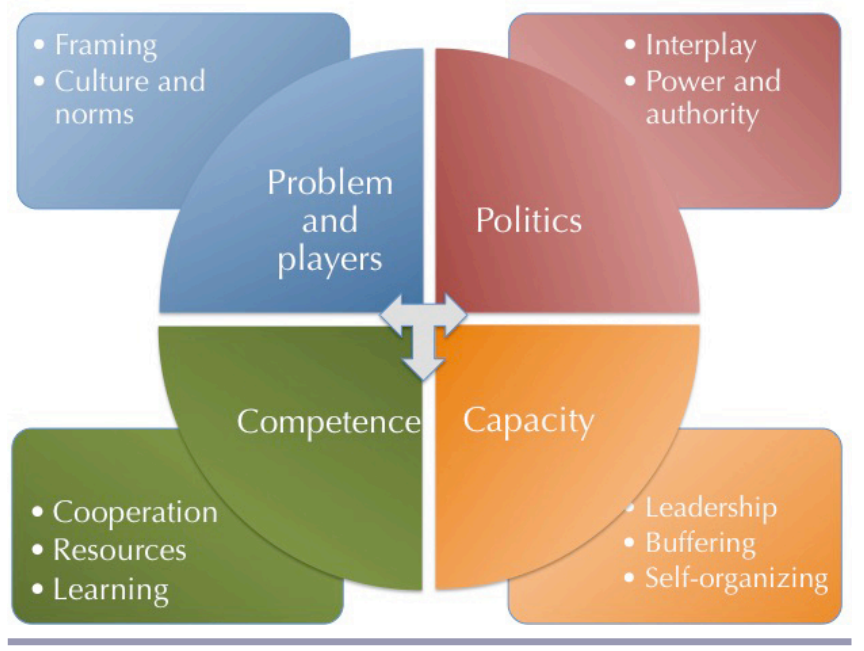

Adaptive governance concepts in the framework were complemented with ideas from the institutional literature to ensure diagnosis considered the conflicting demands for organizations to be more "adaptive" along with their administrative limits. For example, key actors in biodiversity governance often have low levels of discretion and high levels of responsibility (Eakin et al. 2011, Rijke et al. 2012, Wyborn and Dovers 2014). Together, the elements consider the institutional context and capacity for conserving biodiversity. The framework thus leverages the potential of adaptive governance to improve capacity and institutional fitness for conserving biodiversity, while acknowledging the practical limits of actors operating in governmental environments.

Insights from the institutional literature and particularly organizational studies and public administration were fundamental to the design of the framework. For example, buffering in adaptive governance refers to the ability to cope with uncertainty and surprises, and provides backup if one part of the system fails (Boyd and Folke 2011). To enhance this concept for 
use in our framework, the institutional literature on interplay (Oberthür and Gehring 2011, Vatn and Vedeld 2012) and organizational buffering (O'Toole and Meier 2011) was incorporated. In addition to examining institutional responses to biophysical conditions, these documents attend to a diverse suite of causes of institutional interactions. They also highlight how external pressures in institutional environments limit the effectiveness of conservation approaches, and provide strategies for managing these interactions and pressures. Using literature on public administration ensured that fundamental conditions, such as administrative competence, were considered in addition to the more dynamic practices emphasized in adaptive governance.

\section{Interviews and analysis}

The conceptual framework was used to design a set of interview questions that were asked of 51 respondents through semistructured, indepth interviews. The sampling logic was purposive: interviewees who were selected played a role in solving the policy problems associated with landscape-scale biodiversity conservation in the Australian Alps (Table 1). Most government respondents were from middle management, given their critical bridging position between planning and operations (Ansell 2011), although a few were in senior management or played more onground roles. An initial list of interviewees was identified through a key informant who had specialist knowledge of biodiversity governance in the Alps, and some were identified through snowball sampling (Atkinson and Flint 2003).

The conceptual framework provided a lens for qualitative analysis of the interview transcripts. A coding process was first guided by a set of a priori codes from the framework (Creswell 2013), followed by a second level of analysis where emergent themes were identified from coding patterns (Miles and Huberman 1994). The framework elements provided the concepts for analysis across interviews in this second level of analysis (Miles and Huberman 1994), where the data were synthesized into themes. Intercoder reliability was $85 \%$.

Table 1. Individuals interviewed in each category.

\begin{tabular}{|c|c|}
\hline Category & $\begin{array}{l}\text { Number of } \\
\text { respondents }\end{array}$ \\
\hline $\begin{array}{l}\text { State government (Parks Victoria, NSW NPWS, }{ }^{\dagger} \mathrm{ACT}^{*} \\
\text { Parks, Department of Environment and Primary } \\
\text { Industries Victoria) }\end{array}$ & 27 \\
\hline Researchers and consultants & 9 \\
\hline $\begin{array}{l}\text { Federal government (Department of Environment, Parks } \\
\text { Australia) }\end{array}$ & 7 \\
\hline Environmental NGOs and NRM groups ${ }^{\S}$ & 4 \\
\hline Local government & 2 \\
\hline Tourism representatives & 2 \\
\hline TOTAL & 51 \\
\hline \multicolumn{2}{|c|}{$\begin{array}{l}\text { NSW NPWS: New South Wales National Parks and Wildlife Service } \\
\text { ACT: Australian Capital Territory } \\
\text { § NGO: nongovernment organization; NRM: Natural Resource } \\
\text { Management Group }\end{array}$} \\
\hline
\end{tabular}

\section{RESULTS}

All elements of the framework contributed to the suite of questions asked in interviews; however, it was evident after analyzing the interview transcripts that some elements were particularly relevant to the aim of this paper-that is, how institutional conditions enable or constrain the capacity to conserve biodiversity. Most relevant were the themes of administrative competence, learning, buffering, and power and authority (all elements in Fig. 1). Table 2 provides definitions of these critical elements. While other framework elements, such as culture and norms and interplay were important, their results were of less relevance to capacity than those explored below. To illustrate the specific challenges of cross-border conservation, fire and feral horse management are used as examples. Although many other issues were raised in the interviews, these two were most prominent and among the most significant influences on biodiversity in this SES (Lockwood et al. 2014).

\section{The Australian Alps and the institutional context}

The Australian Alps is a mountainous region comprised mainly of protected areas in southeastern Australia (Fig. 2), and includes portions of Victoria, New South Wales (NSW), and the Australian Capital Territory (ACT). This bioregion is reserved mainly as national park. Listed as a national heritage place under federal biodiversity legislation, the Environment Protection and Biodiversity Conservation Act 1999 (Cth) (EPBC Act), the Alps are unique in this relatively flat continent and are recognized internationally by the IUCN as a world center for plant diversity (Davis et al. 1994).

Although ecologically the alpine and subalpine landscapes are similar across borders, the involvement of multiple agencies affects the unity of their management. Australia has a cooperative federalist form of government with a limited set of powers reserved for the national government (Bates 2010). Environmental responsibilities, including land management, lie with state jurisdictions, even for "national" parks. The main institutions with a role in conservation are the state and territory management agencies: Parks Victoria, the NSW National Parks and Wildlife Service (NPWS), and ACT Territory and Municipal Services.

To address the challenge of managing the Alps across these jurisdictional boundaries, the Australian Alps Cooperative Program (AACP) was formally established under a Memorandum of Understand (MOU) in 1986. Partners in the program are the protected area management agencies in all three jurisdictions plus the federal government, which also retains a statutory role through its responsibility for Matters of National Environmental Significance under the EPBC Act, which include threatened species, ecological communities, and National Heritage Places such as the Alps. Despite operating under an MOU, the AACP has survived many political cycles and contentious management issues. It has been presented as an example of an innovative and effective regional management institution (Crabb and Dovers 2007, Jacobs and Anderson 2012, Weiler et al. 2012). While peer support, on-ground cooperation, and learning have been highlighted as key strengths of the program, the AACP has struggled to deal effectively with cross-border issues such as climate change and feral horse management (Crabb and Dovers 2007).

Despite secure tenure as protected areas, the alpine and subalpine ecosystems are facing potential transformation in the face of significant threatening processes, such as climate change, grazing 
Table 2. Summary of framework components salient to this analysis.

\section{Component}

Definition

Administrative competence

The basic financial and human resources and institutional strategies necessary to competently and effectively manage biodiversity. ${ }^{1}$ Includes the ability of public agencies to competently solve problems and fulfill their mission, as well as the scientific skills and knowledge of their staff. ${ }^{2}$

Learning

Learning at its most basic level provides for routine correction and quality control. ${ }^{5}$ Learning that supports adaptive capacity includes practices for gathering information, systematic reflection on performance and processes, revising underlying assumptions, and creatively improvising solutions and adopting a systems approach. ${ }^{6}$

Buffering

Buffering refers to the ability to cope with uncertainty and surprises, and provides backup if one part of the system fails. Redundancy rests on multiple institutions performing the same function. ${ }^{8}$ Response diversity refers to institutions having several different responses to disturbances. ${ }^{9}$ Organizational buffering refers to the strategies used to protect, insulate, or mitigate impacts on performance from the external
environment.

Power and authority

Power is exercised when actors pursue values, interests, and goals. ${ }^{11}$ Authority bestows formal roles and responsibilities on individuals and organizations. ${ }^{12}$ Protected area agencies are formally empowered to act through statute, but authority can be obtained by other means.

Why it matters in this diagnosis

Critical to analyzing general capacity for conservation, and considering how this interfaces with the broader institutional context and calls to be more adaptive. ${ }^{3}$

Understanding how the administrative limits of public agencies affect their ability to deploy their capacity can help inform more realistic but readily achievable forms of adaptive governance. ${ }^{4}$

Analyzing learning routines sheds light on the institutional issues constraining adaptive management ${ }^{7}$ and can inform institutional reforms or strategies for coping with those constraints.

Understanding the successes and failures in efforts to enhance learning can help identify pragmatic pathways for building general capacity to learn and solve problems. ${ }^{1,2}$

Successful buffering enables organizations to achieve policy objectives even as they interact with turbulent institutional environments and deal with uncertainty and instability. ${ }^{10}$

Redundancy and diversity enable adaptive capacity and are critical for accommodating the functional dynamics of ecosystems. ${ }^{6}$

Strategies to effectively deal with political influences are critical to achieving biodiversity outcomes. ${ }^{1}$ Buffering is thus critical to understanding both political and functional institutional fit.

Institutions can both empower and disempower actors, and understanding power dynamics and the allocation of authority are critical to understanding capacity and whether this capacity can be used. $^{13}$

Actors at higher governance levels and in the political and socia arenas also influence how authority is deployed, so power and authority are critical for understanding the impact of the wider institutional context on capacity.

${ }^{1}$ Clement et al. (2016), ${ }^{2}$ Ansell (2011), ${ }^{3}$ Head and Alford (2013), ${ }^{4}$ Rijke et al. (2012), ${ }^{5}$ Ebrahim (2005), ${ }^{6}$ Boyd and Folke (2011), Lockwood et al. (2011), Koontz et al. (2015), ${ }^{7}$ Allen and Gunderson (2011), ${ }^{8}$ Chapin III et al. (2009), ${ }^{9}$ Elmqvist et al. (2003), ${ }^{10}$ O'Toole and Meier (2011), ${ }^{11}$ Gordon (2009), ${ }^{12}$ Hutchcroft (2001), ${ }^{13}$ Berman et al. (2012)

and trampling by feral horses, and fire (Lockwood et al. 2014). Invasive species such as feral horses, and frequent, intense, and large-scale wildfires are already significant ecological issues, with warmer climatic conditions expected to exacerbate them (Lockwood et al. 2014). Feral horses create both ecological damage and social conflicts, thereby repeating longstanding conflicts in the Alps over cattle grazing. While cattle grazing is now banned in the high country, feral horse populations are high and increasing rapidly, at an estimated $22 \%$ per annum (Mackey and Porfirio 2015). Many Australians regard these romantically named "brumbies" as part of the cultural fabric in the Alps (Crabb 2003). Public opposition to shooting has limited management to less effective methods such as "brumby running," where horses are chased and roped by people on horseback.

The extent and frequency of fires has increased markedly in the Alps over the last decade, which has led to changes in policy that are salient to this diagnosis. Major fire events in 2003 burned most of the protected area landscape in the three Alps jurisdictions (see e.g., Doogan 2006, Williams et al. 2006), followed by another massive fire event in Victoria in 2009. Several major inquiries followed these bushfires. In response to strong community and political pressure to reduce fire risk, the Victorian government adopted a hazard reduction burning target of $5 \%$ of all public lands per annum, as recommended by a Royal Commission. Despite evidence that it does not significantly reduce the risk to human lives or assets unless directly around those assets (Gibbons et al. 2012, Clode and Elgar 2014), the other jurisdictions followed suit.

\section{Diagnosis of current arrangements}

\section{Administrative competence}

Accountability was the main feature of administrative competence that was evident in the diagnosis. The effect of narrowly defined accountability measures on the deployment of skills and resources (general capacity), especially the rise in tied funding in lieu of recurrent or baseline funding, was a prominent 
Fig. 2. Location of Australian Alps protected areas.

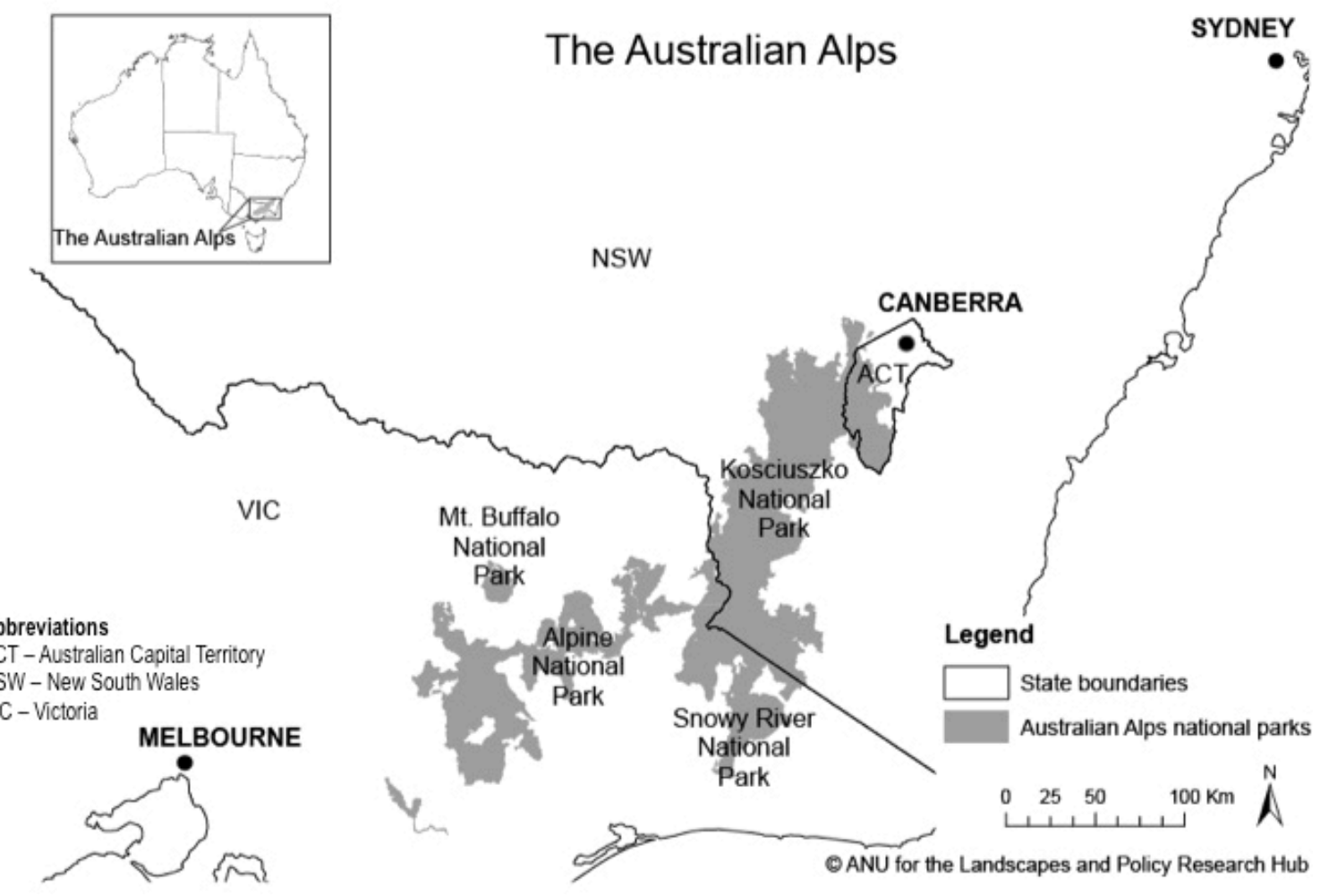

theme related to administrative competence of the various government agencies and departments. The loss of specialists from public agencies was also a concern for many respondents.

A reduction in recurrent funding, especially funding for discretionary activities, was a major concern for government managers. Recurrent, discretionary funding has been replaced by one- to three-year funding that is tied to completion of specific tasks within planned initiatives. Many participants remarked on how this affects adaptive capacity:

Are the structures, strictures, and the rules flexible enough to allow us to adapt in the way that the system dictates?...the way we design our bureaucracy; the way we design our budgets is we allocate something in the order of $95 \%$. Which seems to imply that year in, year out we have 95\% confidence we know how the system operates. It's nonsense. (Victorian government manager)

Agency managers often "dressed up" ongoing projects in new clothes to cope with this funding environment. While this tactic ensures continuity for some projects, it does not address the preallocation of funding to specific activities and a lack of resources for experimentation, reflection, and learning. This affected not just adaptive capacity, but managers thought it encouraged a focus on those activities with quantifiable results in the short term, which is especially out of step with often-slow responses of alpine environments to management interventions. Uncertainty about whether funding would be removed was also a capacity concern, as a gap could lead to mistimed or absent management of critical issues such as horses.
Respondents frequently attributed the displacement of recurrent discretionary funds by tied, initiative funds to broader shifts in the public sector, where increases in accountability and efficiency are pursued through increasingly strict institutional rules and structures. Government respondents frequently discussed how accountability and performance measures were narrowly confined to spending and quantifiable outputs rather than biodiversity outcomes:

We only ever get slammed on accountability stuff because it's the only thing that they can easily measure. We never get slammed for accountability in biodiversity because it's too hard to do. So they just come after the financial stuff. (Federal government respondent)

Respondent discussions of fire management were illustrative of how this misplaced focus affects capacity. The post-fire inquests and inquiries revealed a lack of trust in government agencies and drove the implementation of rigid policies prescribed "from above," including inflexible hectare targets for hazard reduction burning. While respondents understood the need to allocate blame for the fires, tighter, more controlled policies were not viewed as the answer to this complex problem, especially when those policies undermined capacity to actually address the problem. One Parks Victoria respondent articulated this relationship between narrowly defined accountability and competence more generally:

It's very much set up as a controlled environment rather than an empowerment environment...I think if you're going to try to pursue a landscape scale approach, trust, 
consensus, partnership, complementarity are absolutely sort of fundamental to that. And I think it's hard to say look, we're going to have these highly controlled, driven organizations held to high levels of what could be quite narrow accountability and now we want you to operate in this landscape context.

This environment was linked to an increasingly "managerialist" approach to governance. The rise of "professional bureaucrats" was identified as part of a broader theme in which the public service is increasingly trying to apply private sector practices. In particular, a strong emphasis on customer-focused protected area management was considered a hallmark of this mentality:

Our push at the moment is all customer service, customer service, customer relations...does everyone think you're really good? I think science as underpinning work is disappearing, because it's becoming-what's the community view? (NPWS respondent)

This shifting organizational culture was thought to undermine general capacity to effectively manage biodiversity, along with the shrinking numbers of staff with specific ecological expertise and an increase in generalist staff. The sensitive alpine and subalpine environments require specialist skills that are quite rare in Australia. While some generalists had environmental qualifications, higher level managers often had little relevant expertise. For many respondents, this had a concrete impact on their capacity to conserve biodiversity, as a matter of simple arithmetic:

By taking the generalist approach you have people that have to do everything... And if you start allocating percentages next to their time, the amount of time they have dedicated to biodiversity management would be 10\%, maybe 20\%. (Parks Victoria respondent)

\section{Learning}

Protected area management agencies in the Alps have made concerted efforts to build capacity to rigorously monitor management effectiveness. Despite these efforts, administrative and cultural issues have made more systemic change difficult. On an Alps-wide basis, the AACP was praised as a network for fostering learning about on-ground management but had less success in fostering political support or deeper forms of learning that could lead to policy change.

Across the three jurisdictions, there was evidence of learning at the on-ground management level and within organizations but less evidence that this was affecting higher level decisions. The AACP provides a useful network for learning, especially for onground staff and midlevel managers. The AACP provides the conditions to foster adaptive capacity as a useful space for trouble shooting, sharing information, and learning from each other's experiences. While respondents able to provide examples of learning that directly informed management, the failure of that learning to have a more extensive impact on practice, community perceptions, and policy was thought problematic. As one researcher bluntly stated:

Internally it works quite well. In practice though, I'm not sure I can see anywhere where a decision has been changed because of something that has come out of it.
This was especially true of significant cross-border issues like hazard reduction burning and feral horses. Respondents frequently discussed how, despite accumulating scientific evidence of negative ecological consequences for both, they had failed to change policy or community perceptions. This failure to achieve change outside of agencies and at higher levels within the biodiversity governance regime was linked to poor capacity for buffering.

Although managers have improved their understanding of the Alps and capacity to monitor, respondents noted that institutional structures and practices hinder these efforts. For example, while changes need to be obvious and immediate to satisfy financial accountability measures, this is at odds with the need to measure slower variables, reflect on results, and adjust approaches. While accepting the necessity of such requirements, the way these requirements are designed were thought to steer agencies toward monitoring practices that measure outputs (e.g., number of hectares burned or horses removed) rather than outcomes (e.g., vegetation condition). Funding practices in park management agencies were another common source of frustration, with impacts on capacity to learn, especially with respect to making adjustments based on new knowledge or changing circumstances:

One of the hindrances to adaptive management is how much flexibility there is to shift resources or shift responses or actions based on what is learnt... And that's both in terms of, is there enough resilience in the resources available to shift it quickly or shift it to different places? But more importantly, who has the authority to make that decision? And how simple is it for that authority to be deployed? (Parks Victoria respondent)

For many respondents, allocation of decision-making authority to protected area managers was a major concern not just for learning but also for the capacity to make management decisions to effectively address threats to biodiversity. Some also discussed how agencies were trying to develop more systematic approaches to managing threats by linking them to priority assets, but that the culture of "doing stuff" within the protected area agencies would also need to change to support a more outcome-focused approach to conservation. This focus on "doing stuff," however, stemmed from very practical considerations:

It is that real dilemma about if you have $\$ 500,000$ to deal
with a weed, do you spend $\$ 500,000$ spraying it or do you
spend $\$ 250,000$ spraying it and $\$ 250,000$ measuring
effectiveness? And most staff would say we spend
$\$ 500,000$ spraying it because we want to see results. But
then planners and programmers will say: but how do you
know you're achieving anything? (Parks Victoria respondent)

Buffering

Buffering both political and ecological drivers is critical to effective biodiversity governance; however, the diagnostic revealed poor performance in both areas. Inadequate capacity for organizational buffering (Table 2) in protected area agencies has led to misdirected and mistimed responses, which has created both political and functional fit problems. The effect of different approaches across borders had both positive and negative impacts on capacity, which made significant cross-border drivers even 
more challenging but potentially offered benefits in terms of redundancy and diversity.

Government respondents often discussed the political nature of protected area management, and how much time they spent responding to political imperatives rather than following the priorities prescribed in management plans. While many felt their role as bureaucrats was to simply implement policy, this proved difficult when policy requirements were unachievable. For example, the $5 \%$ burning prescription was proving especially difficult to implement practically and without compromising biodiversity assets. Wildfires did not "count" toward the target, and many respondents highlighted that the policy was failing in terms of both risk reduction and biodiversity conservation:

\section{It's really about risk reduction to communities, to keep people safe, so [managers] want to be targeting the highest risk areas, which the basic hectare target doesn't encourage. It actually encourages you to go to places that are easy to burn, away from people. (Parks Victoria respondent)}

Such isolated areas are often the most ecologically valued, and many respondents were concerned about the consequences of repeatedly burning large areas. Inappropriate timing was also a concern, as higher targets were extending the length of the burning programs into drier parts of the year, which increases the risk that fires burn out of control. Both concerns highlight a functional misfit. In addition to being an enormous drain on financial and human resources, several respondents commented that the combination of wildfire and broad-scale hazard reduction burning was transferring the risk into the future and would ultimately lead parts of the system to cross a threshold:

\section{We are putting in a fire regime in Victoria unlike anything it has ever seen before in pre- or post-Aboriginal times or pre- or post-European times...It is based on the assumption, on the wrong assumption, that if you burn an area you will reduce the fuel. It may be true in some areas but it is not true in other ecosystems. It is absolutely totally the reverse in many ecosystems. (Researcher respondent)}

Despite many researchers and managers agreeing that the ecological impacts of burning regimes (combined with intense wildfires) were unprecedented, many felt governments had failed to publicly communicate the risks and benefits of large-scale hazard reduction burning in the Alps. It had become a simple matter of arithmetic in the public sphere:

\section{Somehow in the community debate this very simple equation of $X$ number of thousand hectares being burnt equates to you'll be safe this summer. That's where the debate's been hijacked by that very simplistic analogy that if you see smoke in the air somehow you're going to be safe. (ACT Parks respondent)}

Addressing community perceptions, many respondents noted, would be critical in driving the development of more sensible policies, but some also noted the challenges of communicating the complex (and still changing) ecological science to the broader public. Some respondents made a link between capacity to manage these big ecological problems and a lack of legitimacy and trust among sectors of the community. A general anxiety about the low level of public support was evident, and many highlighted effective community engagement as critical to the future of the parks. These issues were mirrored in feral horse management, which was proving equally problematic in political and public spheres. While most managers considered the technical solution to be relatively straightforward and cost-effective (i.e., shooting from helicopters), and readily supported by scientific evidence, the protected area agencies found the socio-political dimensions of this problem a stronger influence on their capacity to tackle such major issues.

Most respondents felt this failure to address socio-political conditions was particularly acute for feral horses. This issue crosses borders and requires a coordinated approach, but two of the three jurisdictions (Victoria and NSW) had failed to gain public support for effective methods of control. While most lamented the challenges of cooperative federalism and state politics, some respondents felt this could present opportunities for buffering through response diversity:
You create a diversity of governance across that landscape that have objective, foundation reasons for action like legislation...you've got diversity in how you deal with things. That gives you the resilience in the system because it's not just about one line management group making the decision. It's about the tension and dynamics between the line management and its community...so that creates resilience over time that can resist political changes. (Parks Victoria respondent)

Some respondents also noted the potential opportunities for learning and innovation though analysis of different approaches. In practice, however, the diversity of approaches was more often driven by short-term political imperatives rather than intentional effort to test and learn. Respondents recognized that the strategies deployed in NSW and Victoria for feral horse control were not effective, and were grateful that the ACT had adopted a bolder approach. This had not, however, influenced management in the other two jurisdictions, which have the largest populations of feral horses. This tension was evident across a number of different issues - i.e., cooperative federalism enables diversity, but it also inhibits a coherent, consistent landscape-scale approach on important cross-border drivers of biodiversity decline.

\section{Power and authority}

Power dynamics and the allocation of authority were themes underpinning many of the aforementioned results. The influence of politics and community and narrowly defined accountability were less about capacity itself and more about the ability to deploy capacity (Table 2). Concerns regarding disempowerment of public agencies and protected area managers were evident, as was a resignation to a "restricted" authority for Alps managers. Interviewees attributed this restriction to political control and their confined role as policy implementers rather than expert advisors or managers.

Protected area agencies have the formal responsibility for protecting the environment of the parks but have limited discretion to act on this responsibility. While the AACP has offered a place for managers to learn from each other, it was perceived as failing to lead effective cross-border management of issues such as fire and feral horses. In the main, respondents did 
not think this was due to a lack of knowledge or resources; rather it was a problem of ongoing political intervention:

\section{My big picture view is that I think the AACP is a very important entity that exists. I think it's constrained in its potential because of what I've just described [i.e., limited power to address major threats like horses]. I think there's a need for a rethink along the lines of (1) letting the managers manage without political intervention and (2) with trust that they will achieve the right outcomes because there are emerging issues that impact the Australian Alps quite significantly, and that includes wild horses. (Nongovernmental respondent)}

"Letting the managers manage," however, would require greater empowerment of public servants, which few respondents thought possible.

Juxtaposed against the theme of disempowerment is restricted authority, with the roles and responsibilities imposed from higher organizational and political levels in each jurisdiction heavily driven by the politics and policies of the day. Though jurisdictional differences and requirements were identified as a barrier, respondents generally accepted this was the reality of land management in Australia:

The jurisdictions will always have different political priorities for the Alps landscape...that's reality. It's a political environment we live in and governments will always have different policies and views on things; they won't always agree across a landscape like the Alps. (Parks Victoria respondent)

There was also a resigned acceptance that the role of agency managers, as public servants, is to implement government policy rather than define it or influence it in a particular direction, even if they would like to do so:

We can't go along merrily. We might in our positions [in the AACP ] have arguments on how the park should be managed or what's the best thing for the park, but we can't go on doing that without implementing the directions of the government of the day. (NPWS respondent)

This resulted in fluctuating commitment to the AACP over political cycles, and schisms related to contentious issues such as alpine grazing, which periodically reappears on the political agenda. Some respondents also noted the related problem of resourcing the AACP and cross-border management when formal authority - and thus accountability — rests with each jurisdiction. Several respondents lamented the AACP's lack of political engagement, given its potential to lobby for additional funds. Yet this was consistent with the way managers expressed their role in protected area management as implementers of political priorities, not advocates or even expert advisors:

We've got to be pretty clear that irrespective of what our views on different things might be ultimately the government is the government. And if the government has a governor that gets elected on a policy of "blah," it's our role in life to work with the government on implementing that policy, because that's what they want. (Victorian manager)
Although acknowledging that politics is meant to be a reflection of community views, respondents also noted that political decisions are often driven by the views of low-membership special interest groups such as those advocating against culling of feral horses. More broadly, respondents were particularly concerned about the politicization of protected area management and environmental agencies. Instead of senior staff providing "frank and fearless" advice to politicians, many public servants felt pressured to implement policies without question, even if there were negative effects for biodiversity:

The relationship between the government, the public service, the lobby groups...the barrier between those roles often breaks down...And therefore you get senior public servants who can be dismissed on the spot, not being prepared to tell the government that their policy doesn't make sense when you look at the environment. (Parks Victoria respondent)

This again highlights both political and functional fit issues, where the failure to deal with one (politics) affects capacity to effectively address the other (functional dynamics of ecosystems).

\section{DISCUSSION}

Applying the institutional diagnostic has revealed limited capacity to conserve biodiversity - and limited ability to deploy this capacity — within protected area management agencies. This is true of both adaptive and general capacity, and links to the broader socio-political context in which these agencies operate. Narrowly defined accountability inhibits learning and distracts from the core mission of protected area management agencies. While learning is occurring in protected area agencies and across borders through the AACP, there has been less success in translating this to policy change. Issues of disempowerment and restricted authority have also been revealed through this diagnosis. Problems with buffering and an ability to productively deal with political and social influences were identified as fundamental concerns in progressing adaptive governance. Attention to buffering can assist in addressing the problems of fit created by narrow accountability and restricted authority. For the issues of fire and feral horse management, such attention offers a way forward to enhance the performance of biodiversity institutions in the Australian Alps. In the following discussion, we return to the implications of this diagnosis for how institutions enable or constrain capacity to conserve biodiversity in this globally significant protected area and in other protected landscapes with high biodiversity values.

These results point to a critically important issue with the way competence of protected area agency is measured, and measurement drives the choices managers make. Australia, like many other countries across the world, still draws heavily on the principles of New Public Management, as evidenced by respondent discussions of "managerialism" and its impact on management. A legacy of reforms through the 1980s and 1990s, managerialism sought to make public agencies behave more like private organizations (Dixon et al. 1998). The idea was to improve the performance of public agencies by shifting to a results orientation and by incentivizing managers. On the surface, some characteristics may seem similar to adaptive governance: decentralization, providing discretion to managers, serving the 
public (as "customers"), quantitative measurement of indicators, and monitoring and reporting measures (Bach and Bordogna 2011).

Paradoxically, the effect on performance is often negative unless the agencies are able to set undistorted (i.e., in that they align with the agency's objectives) goals where results are under agencies' control (Speklé and Verbeeten 2014). These conditions do not describe the situations facing protected area management agencies. In the case of the Alps, agencies are steered toward outputs such as number of hectares burnt because these are easily measured and provide a form of performance accountability that avoids more difficult and fundamental questions about whether nature conservation outcomes are being achieved. While little research has been done on how managerialism affects adaptive capacity, Eakin et al. (2011) suggest it has a negative influence by overly centralizing political power and impeding efforts to manage complex and long-term problems. This case study suggests that narrowly framed accountability measures could also be a constraint on adaptive capacity.

Accountability was a central theme emerging from this diagnosis, with implications for capacity. While holding public agencies to accountability standards is a core principle of good governance of protected areas (Lockwood 2010), the Alps case study demonstrates the problems with the promulgation of rules and standards that achieve greater control but address only a narrow set of criteria. Current systems strongly focus on hierarchical, legal, and political accountability, thereby de-emphasizing other forms of accountability, such as professional accountability, which would focus on enabling protected area managers to meet their conservation responsibilities (Rainey 2014). While protected area managers thought they were being held accountable upward (e.g., to politicians and higher levels of the public service), this was not complemented by accountability downward (e.g., to the broader community) and to their conservation objectives. This is out of step with the need for expanded accountability measures in protected area governance (Lockwood 2010, Armitage et al. 2012).

Sometimes dubbed "accountability myopia," it is also shortsighted on two counts: (1) it privileges one kind of accountability (i.e., upward) over accountability to communities (i.e., downward) or to the mission of the organization, and (2) it neglects long-term goals by focusing on short-term outputs and efficiency criteria (Ebrahim 2005). In the Alps, there was also a concrete impact on adaptive capacity, where a focus on financial and output accountability means protected area agencies work with fully allocated, tied funds. This not only prevents experimentation and adjustments in an adaptive management cycle but also leaves protected area agencies without financial capacity to respond and adapt to issues as they arise. This diagnosis underscores several functional misfits, where responses are misdirected (e.g., burning areas that were already burned in wildfires), mistimed (e.g., extending the burning season), or absent (e.g., because tied funding is not renewed). While participants knew this could drive some of the Alps system to cross ecological thresholds, they felt constrained by institutional targets. This illustrates how institutional conditions affect not just capacity but the ability to use it.
Learning is critical to both general and adaptive capacity (Table 2 ), and the diagnosis suggests it is the latter where there is poor institutional fit. Successful learning at the operational level has not translated to deeper policy change. The AACP was praised as a useful network for learning, but it was more successful in fostering instrumental learning, where management actions are adapted to achieve conservation objectives (Dovers and Hussey 2013). While protected area agencies have learned a great deal about how fire and feral horses could be better managed, learning at the political and social level for these significant cross-border management issues is still elusive. This has been a long-standing issue with the AACP (Crabb and Dovers 2007).

Both social and political learning are important for supporting institutional change. While the former contributes to changes in beliefs and preferences and reframing the policy problem, political learning enables political actors to affect the agenda and construction of policies (Dovers and Hussey 2013). Accountability myopia may be to blame in part, as limited forms of accountability tend to encourage routine error correction and quality control but discourage more fundamental forms of learning and innovation (Ebrahim 2005). This problem may also be connected to the broader themes of disempowerment and poor buffering capacity revealed in the diagnostic.

The results in this study also illustrate how measures to constrain discretion and disempower protected area management agencies can constrain capacity by undermining performance and reinforce underlying issues of public distrust of governments. Protected area agency respondents were well aware of the need to be responsive to public concerns but objected to the mechanism through which this has occurred. By increasing political control and associated reduction in managerial discretion, the capacity of public agencies to deliver on their responsibilities has been compromised (Ansell 2011).

In what is sometimes called a "spiral of distrust" (Djelic and Sahlin-Andersson 2008), constraining discretion can lead to poor performance and can fuel a negative public view of government agencies, which can lead to the implementation of even stricter controls. In the Alps, protected area agencies shouldered the blame for catastrophic bushfires, and are being asked to burn more as a result. Despite increasing evidence that new blanket burning prescriptions are ecologically unsound (Giljohann et al. 2015), and hazard reduction burning away from communities has little effect on life and property (Penman et al. 2011), protected area agencies are under pressure to burn and lack authority to adapt burning prescriptions based on evidence. Problems of fit here are, again, both political and functional.

The results also provoke deeper questions about the role of the public service. Many respondents in this study saw their roles merely as bureaucrats executing public will or policy implementers translating political directives with as little discretion as possible (Vinzant and Crothers 1996). However, managerial discretion is often necessary for solving local problems and can facilitate interagency cooperation (Thomas 2003). While the idea of "letting the managers manage" raised in this study is consistent with the empowerment prescribed in the adaptive governance literature, it is undermined by long-standing efforts from political and higher level authorities to "make the managers 
manage" (Behn 2001). The results from this study suggest that fostering adaptive capacity is not just about fostering certain practices (e.g., self reflection, monitoring, redundancy, diversity) but is also about rethinking accountability and developing a more substantive decision-making role for public agencies. The concept of "accountable autonomy"(Fung 2004), where middle managers have discretion to adopt and adapt evidence-based strategies that align with outcome accountabilities set at higher levels, offers one realistic pathway between the centralized, rule-based orientation of present institutions and the flexible, decentralized orientation of adaptive governance (Clement et al. 2015).

The results of this diagnosis can be used to build capacity for conserving biodiversity. Strategies to buffer external influences and manage institutional interplay between, for example, hazard reduction burning and biodiversity institutions could positively influence capacity by empowering managers to take action despite conflicting external pressures. This is an under-researched area in public administration, but such buffering could include strategic positioning, networking, defending (e.g., finding ways to maintain capacity during times of financial pressure), and prospecting (e.g., searching for new ways the agencies can address political problems) (Miles and Snow 1978, Meier et al. 2007, O’Toole and Meier 2011). This is less about redesigning institutions and more about managerial strategies to influence governance networks (e.g., through network structure, distributing information) and exploiting opportunities present in the institutional environment (O'Toole 2007, Herranz 2008). Management of institutional interplay could also minimize goal conflict. Collaboration across agencies and jurisdictions to identify synergies between the two regimes or developing a shared overarching institutional framework are two options (Oberthür and Stokke 2011). For fire and biodiversity, this could mean a single policy that jointly considers data on prescribed burning leverage, which essentially considers the reduction in area burnt by wildfire achieved by one unit of prescribed burning (Price et al. 2015) and ecological burning regimes to develop more flexible hectare targets that match the needs of specific ecosystems and conditions.

While the adaptive governance literature often highlights the benefit of diversity (Boyd and Folke 2011) and federalism (Koontz et al. 2015) in providing adaptive capacity, these findings underline tensions between diversity and cohesion that require more research. Authority is restricted in a legal sense by jurisdictional boundaries, which affects capacity to manage cross-border issues. While respondents acknowledged the strength in diversity, this diversity was more a political consequence than a useful management tool or pathway to adaptation and learning. The location of authority within each jurisdiction, and the lack of a formal authority to receive funds, also meant the AACP suffers from crippling resource constraints. One strategy to achieve unity could be to formalize the AACP as a statutory authority (Clement et al. 2015). In addition to shared decision-making, this could provide access to ecosystem service funding (Scarlett and Boyd 2013). In the absence of such reforms, developing buffering capacity could help mitigate the negative effect jurisdictional diversity has on cohesive, effective management of cross-border issues such as fire and feral horses. Intelligently designed cross-border experiments might also leverage this diversity for learning, and could help inform a broader understanding of the effect of diversity on biodiversity outcomes.

\section{CONCLUSION}

This diagnosis of capacity to conserve biodiversity demonstrates how the institutional environments of park management agencies affect both adaptive and general capacity, especially with respect to whether or not that capacity can be employed. Conflicts between narrowly framed accountability measures, the political environment, and the capacity of protected area agencies are relevant to biodiversity governance in other protected areas, especially those managed by public agencies. Such institutional complexity is the norm for protected area governance, where public agencies must not only fulfill conservation responsibilities but also respond to and serve multiple actors and diverse values.

Importantly, our results point to buffering strategies as a potential way forward to deal with competing institutional logics. When confronted by incompatible prescriptions from their institutional environments, protected area agencies cannot just ignore one or the other if they want to achieve their conservation objectives. Rather, the concept of institutional ambidexterity, where organizations learn to excel at two contradictory things simultaneously (Greenwood et al. 2011), offers guidance on how buffering could not only help protected area agencies better deal with these influences but blend both adaptive governance practices with those required to cope with the "managerialist" requirements of the public service. It is difficult to provide blanket prescriptions for how to cultivate ambidexterity in protected area management agencies since this depends largely on specific local and national conditions, but it is possible to create "positive hybrids" that blend both logics through improvised, entrepreneurial responses to these competing pressures (Jarzabkowski et al. 2013, Fossestøl et al. 2015).

Although protected area agencies often deal with institutional complexity in an opportunist and ad hoc manner, building their capacity to buffer external influences offers an intentional way to become more "ambidextrous." In the Alps, one of the most promising ways forward in this regard would be to leverage on the existing AACP, which provides a network for dealing with significant cross-border issues. Governance reforms focusing on enhancing the authority of managers to deal with the major threats to biodiversity attributes, while also leveraging on the potential strength of cooperative federalism, could enhance buffering capacity. Though the specific avenues for reform will differ in other protected areas, similar institutional work to build buffering capacity offers a practical way forward for protected area agencies.

Responses to this article can be read online at: http://www.ecologyandsociety.org/issues/responses. $\mathrm{php} / 8171$

\section{Acknowledgments:}

This research is an output from the Landscapes and Policy Research Hub. The hub is supported through funding from the Australian Government's National Environmental Research Program and involves researchers from the University of Tasmania (UTAS), the Australian National University (ANU), Murdoch University, the Antarctic Climate and Ecosystems Cooperative Research Centre 
(ACE CRC), Griffith University, and Charles Sturt University (CSU). We thank the interviewees for their time and expertise, and Gill Anderson for her contributions and support. We also benefited from the late Roger Good's generous sharing of his deep knowledge and insights on the Australian Alps. The paper was significantly improved through helpful suggestions from reviewers.

\section{LITERATURE CITED}

Allen, C. R., and L. H. Gunderson. 2011. Pathology and failure in the design and implementation of adaptive management. Journal of Environmental Management 92(5):1379-1384. http:// dx.doi.org/10.1016/j.jenvman.2010.10.063

Ansell, C. 2011. Pragmatist democracy: evolutionary learning as public philosophy. Oxford University Press, New York, New York, USA. http://dx.doi.org/10.1093/acprof:oso/9780199772438.001.0001

Armitage, D., R. De Loë, and R. Plummer. 2012. Environmental governance and its implications for conservation practice. Conservation Letters 5(4):245-255. http://dx.doi.org/10.1111/ j.1755-263X.2012.00238.X

Atkinson, R., and J. Flint. 2003. Sampling, snowball: accessing hidden and hard-to-reach populations. In R. L. Miller and J. D. Brewer, editors. The A-Z of social research. SAGE Publications, London, UK.

Bach, S., and L. Bordogna. 2011. Varieties of new public management or alternative models? The reform of public service employment relations in industrialized democracies. International Journal of Human Resource Management 22(11):2281-2294. http://dx.doi.org/10.1080/09585192.2011.584391

Bates, G. M. 2010. Environmental law in Australia. LexisNexis Butterworths, Chatswood, New South Wales, Australia.

Behn, R. D. 2001. Rethinking democratic accountability. Brookings Institution Press, Washington, D.C., USA.

Berman, R., C. Quinn, and J. Paavola. 2012. The role of institutions in the transformation of coping capacity to sustainable adaptive capacity. Environmental Development 2:86100. http://dx.doi.org/10.1016/j.envdev.2012.03.017

Boyd, E., and C. Folke, editors. 2011. Adapting institutions: governance, complexity and social-ecological resilience. Cambridge University Press, Cambridge, UK.

Brunner, R. D. 2010. Adaptive governance as a reform strategy. Policy Sciences 43:301-341. http://dx.doi.org/10.1007/s11077-010-9117$\underline{\mathrm{Z}}$

Butchart, S. H. M., J. P. W. Scharlemann, M. I. Evans, S. Quader, S. Aricò, J. Arinaitwe, M. Balman, L. A. Bennun, B. Bertzky, C. Besançon, T. M. Boucher, T. M. Brooks, I. J. Burfield, N. D. Burgess, S. Chan, R. P. Clay, M. J. Crosby, N. C. Davidson, N. De Silva, C. Devenish, G. C. L. Dutson, D. F. D. Z. Fernández, L. D. C. Fishpool, C. Fitzgerald, M. Foster, M. F. Heath, M. Hockings, M. Hoffmann, D. Knox, F. W. Larsen, J. F. Lamoreux, C. Loucks, I. May, J. Millett, D. Molloy, P. Morling, M. Parr, T. H. Ricketts, N. Seddon, B. Skolnik, S. N. Stuart, A. Upgren, and S. Woodley. 2012. Protecting important sites for biodiversity contributes to meeting global conservation targets. PLOS ONE 7 (3):e0032529. http://dx.doi.org/10.1371/journal.pone.0032529
Butchart, S. H. M., M. Walpole, B. Collen, A. Van Strien, J. P. W. Scharlemann, R. E. A. Almond, J. E. M. Baillie, B. Bomhard, C. Brown, J. Bruno, K. E. Carpenter, G. M. Carr, J. Chanson, A. M. Chenery, J. Csirke, N. C. Davidson, F. Dentener, M. Foster, A. Galli, J. N. Galloway, P. Genovesi, R. D. Gregory, M. Hockings, V. Kapos, J.-F. Lamarque, F. Leverington, J. Loh, M. A. Mcgeoch, L. McRae, A. Minasyan, M. H. Morcillo, T. E. E. Oldfield, D. Pauly, S. Quader, C. Revenga, J. R. Sauer, B. Skolnik, D. Spear, D. Stanwell-Smith, S. N. Stuart, A. Symes, M. Tierney, T. D. Tyrrell, J.-C. Vié, and R. Watson. 2010. Global biodiversity: indicators of recent declines. Science 328(5982):1164-1168. http:// dx.doi.org/10.1126/science. 1187512

Chaffin, B. C., H. Gosnell, and B. A. Cosens. 2014. A decade of adaptive governance scholarship: synthesis and future directions. Ecology and Society 19(3):56. http://dx.doi.org/10.5751/ es-06824-190356

Chapin III, F. S., G. P. Kofinas, and C. Folke, editors. 2009. Principles of ecosystem stewardship: resilience-based natural resource management in a changing world. Springer, New York, New York, USA.

Clement, S., S. A. Moore, M. Lockwood, and M. Mitchell. 2015. Using insights from pragmatism to develop reforms that strengthen institutional competence for conserving biodiversity. Policy Sciences 48:463-489. http://dx.doi.org/10.1007/s11077-015-9222-0

Clement, S., S. A. Moore, M. Lockwood, and T. H. Morrison. 2016. A diagnostic framework for biodiversity conservation institutions. Pacific Conservation Biology 21:277-290. http://dx. doi.org/10.1071/PC15032

Clode, D., and M. A. Elgar. 2014. Fighting fire with fire: Does a policy of broad-scale prescribed burning improve community safety? Society \& Natural Resources 27(11):1192-1199. http://dx. doi.org/10.1080/08941920.2014.905894

Crabb, P. 2003. Managing the Australian Alps: a history of cooperative management of the Australian Alps national parks. Australian Alps Liaison Committee and Australian National University, Canberra, Australian Capital Territory, Australia.

Crabb, P., and S. Dovers. 2007. Managing natural resources across jurisdictions: lessons from the Australian Alps. Australasian Journal of Environmental Management 14(4):210-219. http://dx. doi.org/10.1080/14486563.2007.10648719

Creswell, J. W. 2013. Qualitative inquiry and research design: choosing among five approaches. SAGE Publications, Thousand Oaks, California, USA.

Davis, S. D., V. H. Heywood, and A. C. Hamilton, editors. 1994. Centres of plant diversity: a guide and strategy for their conservation. WWF and IUCN, Gland, Switzerland.

Dietz, T., E. Ostrom, and P. C. Stern. 2003. The struggle to govern the commons. Science 302(5652):1907-1912. http://dx.doi. org/10.1126/science.1091015

Dixon, J., A. Kouzmin, and N. Korac-Kakabadse. 1998. Managerialism - something old, something borrowed, little new: economic prescription versus effective organizational change in public agencies. International Journal of Public Sector Management 11(2/3):164-187. http://dx.doi.org/10.1108/095135$\underline{59810216483}$ 
Djelic, M.-L., and K. Sahlin-Andersson. 2008. Transnational governance: institutional dynamics of regulation. Cambridge University Press, Cambridge, UK.

Doogan, M. 2006. The Canberra firestorm: inquests and inquiry into four deaths and four fires between 8 and 18 January 2003. Coroner, ACT Magistrates Court, Canberra, Australian Capital Territory, Australia.

Dovers, S., and K. Hussey. 2013. Environment and sustainability: a policy handbook. Federation Press, Annandale, New South Wales, Australia.

Dudley, N. 2008. Guidelines for applying protected area management categories. IUCN, Gland, Switzerland.

Dudley, N., K. MacKinnon, and S. Stolton. 2014. The role of protected areas in supplying ten critical ecosystem services in drylands: a review. Biodiversity 15(2-3):178-184. http://dx.doi. org/10.1080/14888386.2014.928790

Eakin, H., S. Eriksen, P.-O. Eikeland, and C. Øyen. 2011. Public sector reform and governance for adaptation: implications of new public management for adaptive capacity in Mexico and Norway. Environmental Management 47(3):338-351. http://dx.doi.org/10.1007/ $\underline{\text { s00267-010-9605-0 }}$

Ebrahim, A. 2005. Accountability myopia: losing sight of organizational learning. Nonprofit and Voluntary Sector Quarterly 34(1):56-87. http://dx.doi.org/10.1177/0899764004269430

Elmqvist, T., C. Folke, M. Nyström, G. Peterson, J. Bengtsson, B. Walker, and J. Norberg. 2003. Response diversity, ecosystem change, and resilience. Frontiers in Ecology and the Environment 1(9):488-494. http://dx.doi.org/10.1890/1540-9295(2003)001[0488: rdecar]2.0.co;2

Folke, C., T. Hahn, P. Olsson, and J. Norberg. 2005. Adaptive governance of social-ecological systems. Annual Review of Environment and Resources 30(1):441-473. http://dx.doi. org/10.1146/annurev.energy.30.050504.144511

Fossestøl, K., E. Breit, T. A. Andreassen, and L. Klemsdal. 2015. Managing institutional complexity in public sector reform: hybridization in front-line service organizations. Public Administration 93:290-306. http://dx.doi.org/10.1111/padm.12144

Fung, A. 2004. Empowered participation: reinventing urban democracy. Princeton University Press, Princeton, New Jersey, USA.

Galaz, V., P. Olsson, T. Hahn, C. Folke, and U. Svedin. 2008. The problem of fit among biophysical systems, environmental and resource regimes, and broader governance systems: insights and emerging challenges. Pages 147-182 in O. Young, L. A. King, and H. Schroeder, editors. Institutions and environmental change: principal findings, applications, and research frontiers. MIT Press, Cambridge, Massachusetts, USA. http://dx.doi.org/10.7551/ mitpress/9780262240574.003.0005

Gibbons, P., L. Van Bommel, A. M. Gill, G. J. Cary, D. A. Driscoll, R. A. Bradstock, E. Knight, M. A. Moritz, S. L. Stephens, and D. B. Lindenmayer. 2012. Land management practices associated with house loss in wildfires. PLOS ONE 7(1):e0029212. http://dx. doi.org/10.1371/journal.pone.0029212
Giljohann, K. M., M. A. McCarthy, L. T. Kelly, and T. J. Regan. 2015. Choice of biodiversity index drives optimal fire management decisions. Ecological Applications 25:264-277. http://dx.doi.org/10.1890/14-0257.1

Goodin, R. E., editor. 1996. The theory of institutional design. Cambridge University Press, Cambridge, UK.

Gordon, R. D. 2009. Power in organizational behaviour. Pages 150-161 in S. Clegg, and C. L. Cooper, editors. The SAGE handbook of organizational behavior: Volume II - macro approaches. SAGE Publications, London, UK.

Greenwood, R., M. Raynard, F. Kodeih, E. R. Micelotta, and M. Lounsbury. 2011. Institutional complexity and organizational responses. Academy of Management Annals 5(1):317-371. http:// dx.doi.org/10.1080/19416520.2011.590299

Gupta, J., C. J. A. M. Termeer, J. Klostermann, S. Meijerink, M. van den Brink, P. Jong, S. Nooteboom, and E. Bergsma. 2010. The adaptive capacity wheel: a method to assess the inherent characteristics of institutions to enable the adaptive capacity of society. Environmental Science \& Policy 13(6):459-471. http://dx. doi.org/10.1016/j.envsci.2010.05.006

Head, B. W., and J. Alford. 2013. Wicked problems: implications for public policy and management. Administration \& Society 47:711-739. http://dx.doi.org/10.1177/0095399713481601

Herranz, J. 2008. The multisectoral trilemma of network management. Journal of Public Administration Research and Theory 18(1):1-31. http://dx.doi.org/10.1093/jopart/mum004

Hill, R., C. Miller, B. Newell, M. Dunlop, and I. Gordon. 2015. Why biodiversity declines as protected areas increase: the effect of the power of governance regimes on sustainable landscapes. Sustainability Science 10:357-369. http://dx.doi.org/10.1007/ $\underline{\text { s11625-015-0288-6 }}$

Hooper, D. U., E. C. Adair, B. J. Cardinale, J. E. Byrnes, B. A. Hungate, K. L. Matulich, A. Gonzalez, J. E. Duffy, L. Gamfeldt, and M. I. O'Connor. 2012. A global synthesis reveals biodiversity loss as a major driver of ecosystem change. Nature 486(7401):105108. http://dx.doi.org/10.1038/nature11118

Hutchcroft, P. D. 2001. Centralization and decentralization in administration and politics: assessing territorial dimensions of authority and power. Governance 14(1):23-53. http://dx.doi. org/10.1111/0952-1895.00150

Jacobs, P., and G. Anderson. 2012. Enhancing connectivity through cooperative management: lessons learned from twentyone years of transboundary programs in the Australian Alps. In M. S. Quinn, L. Broberg, and W. Freimund, editors. Parks, peace, and partnership: global initiatives in transboundary conservation. University of Calgary, Calgary, Alberta, Canada.

Jarzabkowski, P., M. Smets, R. Bednarek, G. Burke, and P. Spee. 2013. Institutional ambidexterity: leveraging institutional complexity in practice. In M. Lounsbury, and E. Boxenbaum, editors. Institutional logics in action, Part B (Research in the sociology of organizations, Volume 39 Part B). Emerald Group Publishing Ltd, Bingley, UK.

Koontz, T. M., D. Gupta, P. Mudliar, and P. Ranjan. 2015. Adaptive institutions in social-ecological systems governance: a 
synthesis framework. Environmental Science \& Policy 53(B):139151. http://dx.doi.org/10.1016/j.envsci.2015.01.003

Le Saout, S., M. Hoffmann, Y. Shi, A. Hughes, C. Bernard, T. M. Brooks, B. Bertzky, S. H. Butchart, S. N. Stuart, and T. Badman. 2013. Protected areas and effective biodiversity conservation. Science 342(6160):803-805. http://dx.doi.org/10.1126/science.1239268

Likens, G. E., and D. B. Lindenmayer. 2012. Integrating approaches leads to more effective conservation of biodiversity. Biodiversity and Conservation 21(13):3323-3341. http://dx.doi. org/10.1007/s10531-012-0364-5

Lockwood, M. 2010. Good governance for terrestrial protected areas: a framework, principles and performance outcomes. Journal of Environmental Management 91(3):754-766. http://dx. doi.org/10.1016/j.jenvman.2009.10.005

Lockwood, M., J. Davidson, M. Hockings, M. Hayward, L. Kriwoken, and R. Allchin. 2011. Requirements for marine biodiversity conservation governance and management in a changing climate. Changing currents in marine biodiversity governance and management: responding to climate change. University of Tasmania, Hobart, Tasmania, Australia.

Lockwood, M., M. Mitchell, S. A. Moore, and S. Clement. 2014. Biodiversity governance and social-ecological system dynamics: transformation in the Australian Alps. Ecology and Society 19 (2):13. http://dx.doi.org/10.5751/es-06393-190213

Mackey, B., and L. L. Porfirio. 2015. Wild horses in the Australian Alps: using satellite data to monitor impact. Landscapes and Policy Hub, University of Tasmania, Hobart, Tasmania, Australia.

McGinnis, M. D. 2011. An introduction to IAD and the language of the Ostrom workshop: a simple guide to a complex framework. Policy Studies Journal 39(1):169-183. http://dx.doi.org/10.1111/ j.1541-0072.2010.00401.x

Meier, K. J., L. J. O’Toole, G. A. Boyne, and R. M. Walker. 2007. Strategic management and the performance of public organizations: testing venerable ideas against recent theories. Journal of Public Administration Research and Theory 17(3):357377. http://dx.doi.org/10.1093/jopart/mul017

Miles, M. B., and A. M. Huberman. 1994. Qualitative data analysis: an expanded sourcebook. SAGE Publications, Thousand Oaks, California, USA.

Miles, R. E., and C. C. Snow. 1978. Organizational strategy, structure, and process. McGraw-Hill, New York, New York, USA.

Mora, C., and P. Sale. 2011. Ongoing global biodiversity loss and the need to move beyond protected areas: a review of the technical and practical shortcomings of protected areas on land and sea. Marine Ecology Progress Series 434:251-266. http://dx.doi. org/10.3354/meps09214

Oberthür, S., and T. Gehring. 2011. Institutional interaction. Pages 215-230 in S. OberthüR, and O. S. Stokke, editors. Managing institutional complexity: regime interplay and global environmental change. MIT Press, Boston, Massachusetts, USA. http://dx.doi.org/10.7551/mitpress/9780262015912.003.0002
Oberthür, S., and O. S. Stokke, editors. 2011. Managing institutional complexity: regime interplay and global environmental change. MIT Press, Boston, Massachusetts, USA. http://dx.doi. org/10.7551/mitpress/9780262015912.001.0001

O'Toole, L. J. 2007. Governing outputs and outcomes of governance networks. Pages 215-230 in E. SØrensen, and J. Torfing, editors. Theories of democratic network governance. Palgrave Macmillan, New York, New York, USA. http://dx.doi. org/10.1057/9780230625006 13

O'Toole, L. J., and K. J. Meier. 2011. Public management: organizations, governance, and performance. Cambridge University Press, Cambridge, UK.

Penman, T. D., F. J. Christie, A. N. Andersen, R. A. Bradstock, G. J. Cary, M. K. Henderson, O. Price, C. Tran, G. M. Wardle, R. J. Williams, and A. York. 2011. Prescribed burning: How can it work to conserve the things we value? International Journal of Wildland Fire 20(6):721-733. http://www.publish.csiro.au/? paper $=$ WF09131

Price, O. F., J. G. Pausas, N. Govender, M. Flannigan, P. M. Fernandes, M. L. Brooks, and R. B. Bird. 2015. Global patterns in fire leverage: the response of annual area burnt to previous fire. International Journal of Wildland Fire 24:297-306. http://dx.doi. org/10.1071/WF14034

Rainey, H. G. 2014. Understanding and managing public organizations. Jossey-Bass, San Francisco, California, USA.

Rijke, J., R. Brown, C. Zevenbergen, R. Ashley, M. Farrelly, P. Morison, and S. van Herk. 2012. Fit-for-purpose governance: a framework to make adaptive governance operational. Environmental Science \& Policy 22:73-84. http://dx.doi. org/10.1016/j.envsci.2012.06.010

Sala, O. E., F. S. Chapin III, J. J. Armesto, E. Berlow, J. Bloomfield, R. Dirzo, E. Huber-Sanwald, L. F. Huenneke, R. B. Jackson, and A. Kinzig. 2000. Global biodiversity scenarios for the year 2100 . Science 287(5459):1770-1774. http://dx.doi.org/10.1126/ science. 287.5459 .1770

Scarlett, L., and J. Boyd. 2013. Ecosystem services and resource management: institutional issues, challenges, and opportunities in the public sector. Ecological Economics 115:3-10. http://dx.doi. org/10.1016/j.ecolecon.2013.09.013

Scott, W. R. 2014. Institutions and organizations: ideas, interests, and identities. SAGE Publications, Thousand Oaks, California, USA.

Speklé, R. F., and F. H. M. Verbeeten. 2014. The use of performance measurement systems in the public sector: effects on performance. Management Accounting Research 25(2):131-146. http://dx.doi.org/10.1016/j.mar.2013.07.004

Thomas, C. W. 2003. Bureaucratic landscapes: interagency cooperation and the preservation of biodiversity. MIT Press, Cambridge, Massachusetts, USA.

Vatn, A., and P. Vedeld. 2012. Fit, interplay, and scale: a diagnosis. Ecology and Society 17(4):12. http://dx.doi.org/10.5751/ es-05022-170412 
Vinzant, J., and L. Crothers. 1996. Street-level leadership: rethinking the role of public servants in contemporary governance. American Review of Public Administration 26(4):457476. http://dx.doi.org/10.1177/027507409602600405

Virji, H., J. Padgham, and C. Seipt. 2012. Capacity building to support knowledge systems for resilient development approaches, actions, and needs. Current Opinion in Environmental Sustainability 4(1):115-121. http://dx.doi.org/10.1016/j.cosust.2012.01.005

Weiler, B., J. H. Laing, and S. A. Moore. 2012. The Australian Alps transboundary partnership: analyzing its success as a tourism/protected area partnership. In M. S. Quinn, L. Broberg, and W. Freimund, editors. Parks, peace, and partnership: global initiatives in transboundary conservation. University of Calgary, Calgary, Alberta, Canada.

Williams, R. J., C. H. Wahren, R. A. Bradstock, and W. J. Müller. 2006. Does alpine grazing reduce blazing? A landscape test of a widely-held hypothesis. Austral Ecology 31(8):925-936. http://dx. doi.org/10.1111/j.1442-9993.2006.01655.x

Wyborn, C. A. 2015. Connecting knowledge with action through coproductive capacities: adaptive governance and connectivity conservation. Ecology and Society 20(1):11. http://dx.doi. org/10.5751/es-06510-200111

Wyborn, C., and S. Dovers. 2014. Prescribing adaptiveness in agencies of the state. Global Environmental Change 24:5-7. http:// dx.doi.org/10.1016/j.gloenvcha.2013.11.020

Young, O. R. 2008. Building regimes for socioecological systems: institutional diagnostics. In O. Young, L. A. King, and $\mathrm{H}$. Schroeder, editors. Institutions and environmental change: principal findings, applications, and research frontiers. MIT Press, Cambridge, Massachusetts, USA. http://dx.doi.org/10.7551/ mitpress/9780262240574.003.0004 